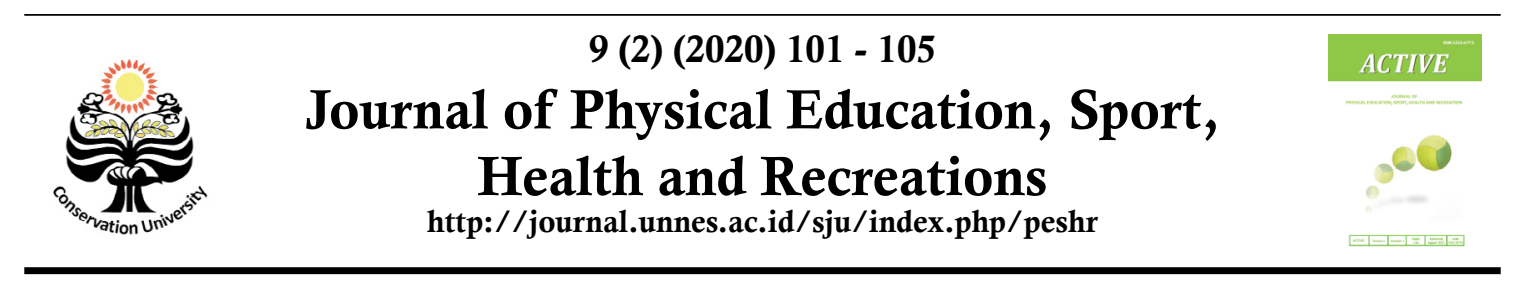

\title{
Effectiveness of ACIK (Anak Ceria dan Kreatif) Gymnastics Model Implementation to Improve Child's Kinesthetic Basic Motion
}

\author{
Noviria Sukmawati ${ }^{1 \bowtie}$, Firmansyah Dlis $^{2 \bowtie}$, Ramdan Pelana $^{3 \bowtie}$, Selvi Atesta \\ Kesumawati $^{4 \bowtie}$
}

Graduate Program, State University of Jakarta, Indonesia ${ }^{123}$

Bina Darma University of Palembang, Indonesia ${ }^{4}$

\begin{tabular}{l} 
Article History \\
\hline Received 11 April 2020 \\
Accepted June 2020 \\
Published June 2020 \\
\hline
\end{tabular}

Keywords:

ACIK (anak ceria dan

kreatif) gymnastics model; kinesthetic; basic motion; kindergarten students

\begin{abstract}
Kinesthetic intelligence is the movement to coordinate body movements using parts or the whole body to communicate and solve problem parts. This research uses a quantitative approach with a quasi-experimental method (quasi-experimental). The design used in this study is the one group control pretest-posttest design. This researcher used the TGMD 2 test instrument. Based on the results of the effectiveness test, it was proven that the average value of the experimental class's posttest effectiveness test results was $77.4048 \%$ greater than the results of the control class posttest score of $50.1343 \%$. Then it can be concluded that the ACIK (Anak Ceria dan Kreatif) gymnastics model proved to be effectively applied to improve the kinesthetic basic motion of kindergarten students. From the results of these studies, it is necessary to submit a suggestion that is especially for kindergarten teachers should be more creative and innovative in designing and delivering learning materials, especially in physical motor material.
\end{abstract}

\section{How to Cite}

Sukmawati, N., Dlis, F., Pelana, R., \& Kesumawati, S. A., (2020). Effectiveness of ACIK (Anak Ceria dan Kreatif) Gymnastics Model Implementation to Improve Child's Kinesthetic Basic Motion. Journal of Physical Education, Sport, Health and Recreation, 9(2), 101-105.

(C) 2020 Universitas Negeri Semarang

\footnotetext{
Correspondence address :

E-mail: NoviriaSukmawati_7217167413@mahasiswa.unj.ac.id ramdanpelana@yahoo.com firmansyahdlis@yahoo.com kesumawati@binadarma.ac.id
}

p-ISSN 2460-724X

e-ISSN 2252-6773 


\section{INTRODUCTION}

Early childhood education (PAUD) is a coaching effort aimed at children from birth to the age of six years which is carried out through the provision of educational stimuli to help physical and spiritual growth and development so that children have the readiness to enter further education. As stated in (Permendikbud No 137, 2014) explains, "Early Childhood Education standards aim to ensure the quality of early childhood education to provide a foundation for, conducting educational stimulants in helping physical and spiritual growth and development by the level of achievement and development children, optimizing children's development holistically and integratively, as well as preparing the formation of attitudes, knowledge, and skills".

Early childhood is an individual who is experiencing a very rapid development process and is very fundamental for the next life (Solehuddin, 2000). In general, the goal of early childhood education is to develop a variety of children's potential from an early age in preparation for life and be able to adjust to their environment. Children's education can be interpreted as an effort to optimize the extraordinary potential of children that can be framed in education, integrated coaching, and mentoring. There are four types of PAUD in Indonesia namely; 1) Kindergarten, 2) Play Group, 3) Day Care, and 4) Similar PAUD (Similar to Play Group).

Kindergarten education is a formal educational institution for children before entering the next level of education. This institution is considered important to develop children's potential optimally. Kindergarten education aims to help students develop a variety of potential both psychic and physical including moral, social, physical, linguistic and cognitive aspects. According to (Rismayanti, 2013) explains that motor development is strongly influenced by the brain organ, through play stimulates the growth of muscles when the child jumps, throws, or runs. Kindergarten students can remember memorization of course with good stimulation will be beneficial for children. Thus the need for physical activity to improve the child's physical motor through correct basic motion activities, so that the achievement of learning objectives in the development of children's basic motion.

A physical activity using bodywork is intended so that the child has the development of body movements that are harmonious and harmonious so that one day can develop good motion. The ability to move is called kinesthe- tic intelligence. Based on the results of research from (Yuningsih, 2018) explains that "kinesthetic intelligence is the ability to use limbs in solving problems to express ideas, ideas demonstrated through practice so that goals can be achieved such as running, dancing, jumping and so on". This opinion is in tune with the opinions of (Tadkiroatun, 2008) which reveal that "kinesthetic intelligence of intelligence is related to the ability to use whole-body movements to express ideas and feelings and the skill to use hands and feet to create or change something". Also, according to (Aeni et al., 2019) explained, "this intelligence includes specific physical abilities, such as coordination, balance, skills, strength, flexibility, speed and accuracy of receiving stimuli, touches, and textures". Also delivered by (Nutrition, 2018) revealed that "kinesthetic intelligence is characterized by the ability to control body movements and the ability to manage objects".

As for one way to develop kinesthetic intelligence is by the application of rhythmic gymnastics, namely ACIK (Anak Ceria dan Kreatif). ACIK (Anak Ceria dan Kreatif) gymnastics is a series of exercises arranged by the author that are adjusted to the characteristics of kindergarten students and prioritizes basic elements of motion such as locomotor, non-locomotor and manipulative. Through gymnastic movements, the child will be free of expression so that children will find new experiences and by following the rhythm of the child freer to move, imagine and dare to face new challenges. (Sujiono, 2009) argues that, "approaches in rhythmic motion activities must emphasize a creative and flexible methodology that places the process of movement and self-expression on the rhythm more important than the resulting pattern of motion".

The benefits of rhythmic gymnastics for kindergarten students are the main activities that are most useful for developing physical components and motor abilities (Mahendra, 2010). Related to the benefits of gymnastics as physical activity of motion and song, (Galih Dwi Pradipta, 2017) argues that, "through physical activity, movement and song can make a major contribution to balance the brain of early childhood, by combining physical activity (sports) and listening activities music or singing, can help brain development. Children follow the song by moving all limbs, it can be useful to stimulate the functioning of both hemispheres of the brain both the left brain and right brain. Rhythmic exercises are done in a correct and orderly manner in a period that is quite possible to, creating a pleasant atmosphere during lessons and improving emotional conditions, can 
create an optimal stimulus for the nervous system that is beneficial to the educational process, stimulates children to move, encourages a state of relaxation and calmness, facilitating the rhythmic performance of movements, facilitating the internalization of motor abilities and special abilities for rhythmic gymnastics, contributing to the development of memory and distributive attention.

But in reality, the field is not as expected, it can be seen from the implementation of kindergarten exercises in Belitang OKU Timur, gymnastics are performed only once a week which is a healthy happy gymnastics, in every activity that requires motor movements of children is slow and lacking enthusiasm so that the child kinesthetic it has not developed optimally because when children do basic movements, they become confused, such as lack of development of street children in place, lack of development of children in standing on one leg (balance), lack of development of children in swinging hands, and lack of enthusiasm of children in doing rhythmic gymnastic movements. In previous research results, the application of rhythmic gymnastics in improving the kinesthetic intelligence of kindergarten children has been investigated by (Yuningsih et al., 2019) which results in research that rhythmic gymnastics can affect kinesthetic intelligence in children in Kurnia Illahi districts Tanah Datar.

Based on the problems mentioned above, it is necessary to have a solution to facilitate kindergarten students in learning basic motion kinesthetic, and stimulation is needed that can develop the abilities and potential possessed by kindergarten students in learning basic motion kinesthetic. So the teacher's role is very influential in the implementation of motor physical learning because of the teacher as a mediator in the implementation of learning in kindergarten. Because with the implementation of a new learning model, especially in providing basic motion kinesthetic material so that the expected goals can be achieved properly. Thus the central issue in this research is, "The Application of the Use of ACIK (Anak Ceri dan Kreatif) Gymnastics to Improve Child's Kinesthetic Basic Motion”.

\section{METHODS}

This research was conducted at the TK Sidomulyo Belitang OKU Timur. With a total population of 60 kindergarten students, 30 children as the experimental group, and 30 other children as a control group. This research uses a quantitative approach with a quasi-experimental method (quasi-experimental). With the design used in "the one group control pretest-posttest design" (Maksum, 2012). The following is a research design Table 1 in the model effectiveness test.

Table 1. Research Design in Model Effectiveness Test

\begin{tabular}{cccc}
\hline Subject & Pre-Test & $\begin{array}{c}\text { Treat- } \\
\text { ment }\end{array}$ & Post-Test \\
\hline $\mathrm{R}$ & $\mathrm{Q} 1$ & $\mathrm{P}$ & $\mathrm{Q} 2$ \\
$\mathrm{R}$ & $\mathrm{Q} 2$ & - & $\mathrm{Q} 4$ \\
\hline
\end{tabular}

This researcher used the TGMD-2 test instrument (Ulrich, 2000). In research from (Pratiwi et al., 2016) explains that "TGMD-2 uses a process measure, where the measurement is more emphasized on the qualitative aspects of movement and how children move their bodies in performing motoric tasks". The scoring on this test is a score of 1 if successful in carrying out the task, and 0 if it fails. Add up the scores from the 2 trial tests to get a total score for each performance criterion. Add a total score for each performance criterion to get a skill score. At the end of the subtest (locomotor test and Object control test) add up to 6 skill scores to get a raw score. A high score indicates that the child's performance is good, whereas a low score means that the child's performance is not good (Bakhtiar, 2015). The data analysis technique is carried out through three stages, namely, the description of the data stage, the test requirements analysis phase, and the hypothesis testing stage. Testing the hypothesis in this study using SPSS.

\section{RESULTS AND DISCUSSION}

Based on data from the TGMD 2 test results in kindergarten children aged 5-6 years. The results obtained that after being treated with the ACIK gymnastic model (Cheerful and Creative Children), an increase in the experimental class. With an average TGMD 2 test result $=47.27$ and a standard deviation of $=1.874$ in the experimental group, while an average TGMD 2 test results in the control group $=43.57$ with a standard deviation $=2,417$. It can be concluded that the results of the experimental class TGMD 2 test are better than the results of the control class TGMD 2 test.

\section{Hypothesis testing}

Hypothesis testing is done by using two unpaired sample tests, namely independent sample t-test. In writing from (Hidayat, 2014) explains that "independent t-test is a comparative test or different test to find out whether there are signif- 
icant differences in a mean or mean between 2 free groups that have interval/ratio data. The two free groups referred to here are two groups that are not paired, meaning the source of data comes from different subjects ".

In the Independent Samples Test output results above, the value of $t=6.627$ and Sig. (2-tailed) or p-value $=0,000<0.05$ or Ho is rejected. So thus there is a significant difference between the results of the TGMD 2 test in children after using the ACIK (Anak Ceria dan Kreatif) gymnastics model.

\section{Effectiveness Test}

Then the $\mathrm{N}$-gain Score test is performed to determine the effectiveness of the application of the ACIK (Anak Ceria dan Kreatif) gymnastics model to improve the kinesthetic basic motion of kindergarten students.

Based on the results of the $\mathrm{N}$-gain score above, it shows that the average value of the $\mathrm{N}$ gain score for the experimental class is $77.4048 \%$ included in the "effective" category. With a minimum $\mathrm{N}$-gain score of $50.00 \%$ and a maximum $\mathrm{N}$-gain score of $100 \%$. While for the average $\mathrm{N}$ gain score for the control class (image media) is $50.1343 \%$ included in the category of "less effective". With a minimum N-gain score of $28.57 \%$ and a maximum $\mathrm{N}$-gain score of $75.00 \%$. So thus the ACIK gymnastic model (Anak Ceria \& Kreatif) proved to be able to improve the kinesthetic basic motion of kindergarten children. The results of this discussion are in tune with the results of research from (Azmi, 2018) with the results of research that rhythmic gymnastics can develop kinesthetic intelligence in early childhood.

Based on the results of the above TGMD2 test results obtained that the results of the experimental class TGMD2 test are better than the results of the control class TGMD2 test proven by an increase in the experimental class. While the results of the hypothesis test results show that there are significant differences between the results of the TGMD 2 test in children after using the ACIK gymnastics model (Anak Ceria \& Kreatif). And based on the results of testing the effectiveness of the application of the ACIK gymnastics model (Anak Ceria \& Kreatif), it was found that the average $\mathrm{N}$-gain score for the experimental class was higher than the average value of the $\mathrm{N}$-gain score in the control class. Then it can be stated that the ACIK gymnastics model (Anak Ceria \& Kreatif) is effectively used to improve the kinesthetic basic motion of children.

(Suyadi, 2014) explains that kinesthetic in- telligence is one's ability to combine physical and mind so as to produce perfect movements. This means that kinesthetic intelligence is a combination of good movements between mind and other bodies. To achieve good basic kinesthetic motion there needs to be an appropriate strategy

in the learning process. This refers to the results of previous research, namely research from (Rahardjo \& Hidayati, 2019) which results in research that there is the optimization of kinesthetic intelligence through motion and song learning strategies in terms of planning, design, processes at TK Tunas Rimba 1 and TK Insan Cita Madani Samarinda. In addition, in other studies (Patriana et al., 2017) explained that learning motion and song is the activity of learning to sing through moving. So the importance of learning motion and song for early childhood in practicing gross motor skills, improving or developing the ability to process the body, control the body, especially kinesthetic intelligence. ACIK Gymnastics (Anak Ceria \& Kreatif) is a gymnastic movement that is adapted to the motor development of kindergarten children. ACIK Gymnastics (Anak Ceria \& Kreatif) is included in the learning of motion and songs because in ACIK Gymnastics (Anak Ceria \& Kreatif) that have been developed there are songs based on 5 themes namely myself, animals, transportation, profession, and the environment. children move to the rhythm of the song and follow the movement according to the theme.

\section{CONCLUSION}

Based on the results of the aforementioned effectiveness test, it is proven that the average value of the experimental class's post-test effectiveness test results is $77.4048 \%$ greater than the post-test results of the control class that is equal to $50.1343 \%$. Then it can be concluded that the ACIK (Anak Ceria dan Kreatif) gymnastics model proved to be effectively applied to improve the kinesthetic basic motion of kindergarten students. From the results of these studies, it is necessary to submit a suggestion that is especially for kindergarten teachers should be more creative and innovative in designing and delivering learning materials, especially in physical motor material.

\section{REFERENCES}

Aeni, A. Q., Permanasari, A. T., \& Khosiah, S. (2019). Meningkatkan Kecerdasan Kinestetik Melalui Kegiatan Senam Irama. Seminar Nasional PGPAUD 2019. http://semnaspgpaud.untirta. ac.id/index.php/ 
Azmi, N. (2018). Efektivitas Senam Irama untuk Mengembangkan Kecerdasan Kinestetik Anak Usia Dini di Taman Kanak-Kanak Azkia Sukabumi Bandar Lampung. http://repository.radenintan.ac.id/id/eprint/4394

Bakhtiar, S. (2015). Merancang Pembelajaran Gerak Dasar Anak. UNP PRESS.

Galih Dwi Pradipta. (2017). Strategi Peningkatan Keterampilan Gerak Untuk Anak Usia Dini Taman Kanak-Kanak B. Jendela Olahraga, Vol 2(No 1), h. 143.

Hidayat, A. (2014). Tutorial Independen T Test dengan SPSS. Https://Www.Statistikian.Com. https://www.statistikian.com/2014/04/independen-t-test-dengan-spss.html

Mahendra, A. (2010). Permainan Anak Dan Aktivitas Ritmik. Erlangga.

Maksum, A. (2012). Metode Pendekatan dalam Olahraga. Unesa University Press.

Nutrition, W. (2018). 9 Cara Kembangkan Kecerdasan Kinestetik Anak. Https://Www.Parentingclub.Co.Id. https://www.parentingclub.co.id/ smart-stories/9-cara-kembangkan-kecerdasankinestetik-anak

Permendikbud No 137. (2014). Standar Nasional Pendidikan Anak Usia Dini.

Pratiwi, F., Joefiani, P., \& Wungu, E. (2016). Adaptasi Alat Ukur Test Of Gross Motor Development-2 Pada Anak Usia 4-6 Tahun Di Kota Bandung [Universitas Padjadjaran]. http:// pustaka.unpad.ac.id/archives/141095
Rismayanti, C. (2013). Mengembangkan Keterampilan Gerak Dasar Sebagai Stimulasi Motorik Bagi Anak Taman Kanak-Kanak Melalui Aktivitas Jasmani. Jurusan Pendidikan OlahragaFakultas Ilmu KeolahragaanUniversitas Negeri Yogyakarta, 6(1), 64-68.

Solehuddin, M. (2000). Konsep Dasar Pendidikan Prasekolah. Fakultas Ilmu Pendidikan UPI.

Sujiono. (2009). Konsep Dasar Pendidikan Anak Usia Dini. PT Indeks.

Tadkiroatun, M. (2008). Pengembangan Kecerdasan Majemuk. Universitas Terbuka.

Ulrich, D. A. (2000). Test of Gross Motor Development: Examiner's Manual (Second Edi). McGraw-Hill Inc.

Yuningsih, R. (2018). Peningkatan Kecerdasan Kinestetik Melalui Pembelajaran Gerak Dasar Tari Minang (Penelitian Tindakan Kelompok B1 di TK Negeri 01 Sungai Pagu Kabupaten Solok Selatan). Jurnal Tumbuh Kembang: KajianTeori Dan Pembelajaran PAUD, 5(2). https:// ejournal.unsri.ac.id/index.php/tumbuhkembang/article/view/7581/3829

Yuningsih, R., Akmariani, C., \& Fitriani, W. (2019). Pengaruh Senam Irama Terhadap Kecerdasan Kinetetik pada Anak di TK Kurnia Illahi Kabupaten Tanah Datar. Tumbuh Kembang:Kajian Teori Dan Pembelajaran PAUD, 6(1). https:// ejournal.unsri.ac.id/index.php/tumbuhkembang/article/view/8347. 